3. Ломов Б.Ф. Формирование графических знаний и навыков у учащихся / Б.Ф. Ломов.- М. : Политиздат, 1959. - 267с.

4. Менчинская Н.А. Психология применения знаний к решению учебных задач / Н.А. Менчинская // Психология применения знаний к решению учебных задач. - М. : Изд-во АПН РСФСР, 1958. - 416 с.

5. Ройтман И.А. Методика преподавания черчения/ И.А.Ройтман. - М. : Гуманит.изд.центр ВЛАДОС, 2000. - 240с.

Стаття надійшла до редакції 01.06.2012 р.

УДК 6(07)

Н. В. Дубова, кандидат пед. наук, доцент,

Уманський ДПУ імені Павла Тичини

\title{
ПСИХОЛОГО-ПЕДАГОГІЧНІ ОСНОВИ ФОРМУВАННЯ ЕЛЕМЕНТІВ ДИЗАЙНЕРСЬКОГО МИСЛЕННЯ СТАРШОКЛАСНИКІВ НА УРОКАХ ТЕХНОЛОГІї
}

Дубова Н.В. Психолого-педагогічні основи формування елементів дизайнерського мислення старшокласників на уроках технології.

У статті розглянуто та проаналізовано сукупність психолого-педагогічних умов формування елементів дизайнерського мислення старшокласників на уроках технології.

Ключові слова: дизайнерське мислення, мистецька освіта, вчитель технології, старшокласники, художньо-конструкторська діяльність.

Дубова Н. В. Психолого-педагогические основы формирования элементов дизайнерского мыциления старшеклассников на уроках технологи.

В статье рассмотрен и проанализирован комплекс психолого-педагогических условий формирования элементов дизайнерского мышления старшеклассников на уроках технологии.

Ключевые слова: дизайнерское мышление, художественное образование, учитель технологии, старшеклассники, художественно-конструкторская деятельность.

Dubova N. Psychological and pedagogical basis for the formation of elements of design thinking in the classroom high school technology.

In the article considers and analyzes the complex psychological and pedagogical conditions of the elements of design thinking senior pupils technologies.

Key words: design thinking, art education, technology teacher, high school students, art and design activities.

Постановка проблеми. Залучення учнів до основних видів проектнотехнологічних робіт дозволяє долати усе нові й нові перепони на шляху пізнання, тобто оволодівати усе складнішими знаннями, вміннями й навичками. Розвиток учнів відбувається значно ефективніше, якщо в процес навчання вводяться елементи творчості та використовується художньоконструкторський підхід до виконання об'єктів праці, що позитивно впливає на підготовку і виховання молодого покоління.

Актуальність дослідження. Для розв'язання задач естетичного i трудового виховання наявні різноманітні педагогічні засоби. Серед них художньо-конструкторська діяльність посідає одне 3 провідних місць, оскільки дозволяє розв'язувати ці питання комплексно. Вироби художньоконструкторського мистецтва органічно поєднують в собі естетичний i 
утилітарний моменти. Розвинені художньо-конструкторські здібності необхідні нині практично всім фахівцям будь-якої галузі виробництва.

Художнє конструювання - це процес раціонального проектування виробів з урахуванням законів гармонії і краси. Естетична виразність має досягатися як результат послідовного здійснення конструкторського задуму [1].

Аналіз останніх досліджень і публікацій. Проблема творчого розвитку особистості, її художньо-конструкторської освіти та естетичного виховання в умовах середньої школи висвітлені в наукових працях Д. Говорун, Д.Єльнікова, О.Коваль, В. Кузіна, Б. Мейлах, Н. Митропольської, М. Ростовцева, В. Сидоренка, Д. Тхоржевського, С. Шорохова.

Метою статті $€$ визначення та обгрунтування психолого-педагогічних умов формування дизайнерського мислення старшокласників на уроках технології.

Виклад основного матеріалу. У процесі спеціально організованих занять можна формувати в учнів особливий стиль мислення, для якого характерним $\epsilon$ розуміння основних критеріїв гармонійної речі, відчуття стилю, естетичне ставлення до світу речей (тобто дизайнерське мислення) за дотримання певних умов:

- якщо буде реалізовано сукупність естетико-педагогічних умов розвитку творчого мислення (навчально-дизайнерських, соціальноемоційних, евристично-дидактичних, індивідуально-творчих);

- єдність емоційної, інтелектуально-оцінної і проектно-практичної діяльності в процесі навчання;

- постановка і рішення дизайнерських проблемних ситуацій на основі спеціальних знань;

- розкриття в процесі навчання духовно-змістовного змісту речей через їх дизайнерські якості;

- залучення учнів до активних самостійних спостережень природи, довкілля [2].

Розвиток дизайнерського мислення учнів здійснюється шляхом організації продуктивної творчої діяльності на базі формування у них елементів графічної грамоти і технічних уявлень, шляхом залучення учнів до процесу рішення елементарних конструкторських задач [3].

Ми вважаємо, що на уроках технології необхідно показати, що художній початок присутній під час створення всіх предметів довкілля i кожна людина має уміти створювати красиві речі.

Задля цього можна використовувати елементи художнього конструювання, які передбачають в предметі:

- єдність кольору і форми;

- поєднання матеріалу і форми;

- відповідність форми призначенню;

- пропорційність різних форм у композиції.

Цей комплекс знань ми називаємо художньо-конструкторським, або дизайнерським [1]. 
Художнє конструювання, будучи одним із видів художньої творчості, дозволяє формувати творчі здібності, сприяє вихованню естетичної культури в учнів, і в той же час надає змогу закріпити і поглибити знання, уміння, навички, набуті ними на уроках трудового навчання, також розвивається художній смак, здатність знаходити адекватні засоби для вираження створюваного образу, формуючи творчий потенціал учнів, а також знання, уміння, навички в області художньо-трудової діяльності [1].

Водночас, художнє конструювання, як будь-який продуктивний вид діяльності, розкриває можливості для моделювання різних типів взаємодії учнів в процесі діяльності, що виховує почуття обов'язку, відповідальності, уміння підкорятися вимогам групи і творчо працювати в колективі, виявляти взаємодопомогу, засвоювати норми суспільної поведінки.

У процесі конструювання в учнів інтенсивніше розвивається просторова уява, виробляється здатність швидко переходити від мислення до дії, наперед обмірковується зміст своєї роботи, планування іiі, формується i розвивається точність і спритність рухів тощо.

Вплив довкілля на учнів відбувається в процесі діяльності. Старшокласники більш емоційно сприймають зміни планування і обстановки приміщення, достатньо правильно орієнтуються в цих змінах. Також вони вважають за краще художньо-образне оформлення довкілля, їх привертає оригінальна конструкція, незвичайне колірне оброблення, рухливість предметів.

Технічна естетика, що вивчає закономірності формування довкілля, вимагає від проектувальників створення зручних, корисних і красивих речей. До всіх функціональних, ергономічних і економічних вимог додаються i такі, як відповідність кольору i форми, форми i матеріалу, форми $\mathrm{i}$ призначення. Останні з перерахованих вимог можна назвати естетичними, оскільки їх сукупність дозволяє судити про красу речей. Впливаючи на органи чуття учня, предмети викликають певне ставлення до них. Постійне зіткнення з красивими предметами, сприяє формуванню естетичного смаку, естетичної культури [3].

У процесі навчання і виховання змінюються різні сторони психічної діяльності учнів, відбувається накопичення i зміна способів, умінь виконувати все більш різноманітні дії, змінюються знання і уявлення, формуються нові мотиви і інтереси. 3-поміж всієї різноманітності цих змін психологи виокремлюють загальні і визначальні властивості:

1. Психологічна структура діяльності.

2. Рівень розвитку механізмів мислення.

Окрім названих властивостей необхідно розвивати в учнів зорову пам'ять, «зоровий досвід», уміння оцінити зорові враження.

Отже, необхідно розвивати такі властивості учнів:

1. Творча уява.

2. Зорове сприйняття і зорова пам'ять.

3. Цілеспрямованість дій, уміння змінювати їх залежно від зміни мети.

4. Уміння співвідносити, синтезувати абстрактні і конкретні знання. 
Формуванню вказаних властивостей учнів можуть сприяти художньоконструкторські знання і уміння, якими опановують учні під впливом довкілля і в результаті спеціального навчання.

Перед учнями виникають технічні задачі, що вимагають розумової напруги. Як база їх розв'язання, розвитку конструкторських здібностей вчителі визначають конструкторсько-технічні знання, уміння, які необхідно формувати в учнів:

- знання і уміння 3 використання інструментів та оброблення матеріалу;

- знання властивостей матеріалу і технології;

- уміння аналізувати трудові завдання, планувати і застосовувати знання на практиці.

Сприймаючи предмети довкілля, співвідношення різних форм, поєднання кольорів, а також отримуючи відповідні знання на уроках, учні засвоюють певну систему знань про різні комбінації, засобів виразності в художньому конструюванні [1].

Ці знання сприяють формуванню в учнів просторових уявлень, конструкторських знань i знань про композицію. Отже, художньоконструкторські знання необхідно формувати ще з молодшого віку, оскільки вони допомагають сприйняттю краси довкілля і розвитку просторових уявлень.

У процесі художнього конструювання вчителю технології необхідно навчати учнів використовувати різні засоби гармонізації форми. Отже, вони повинні вміти:

- чергувати різні узгоджені елементи, які сприяють ясності, чіткості і стрункості композиції (ритмічність); досягати рівноваги, статичності форми (симетрія); створювати у формі динаміку в межах цілого (асиметрія);

- встановлювати пропорції в своїй єдності і складати пропорційногармонійний лад (пропорція);

- бачити порядок, симетрію та обмеженість елементів у розмірах у відповідності з цілим (пропорційність);

- виражати домірність або відносну відповідність розмірів, які сприймає людина, розмірам форм самої людини (масштаб і масштабність);

- передавати у формі рух (динамічність);

- створювати композицію зі стійкістю (статичність);

- досягати художньої виразності в конструкції (контраст і нюанс);

- досягати гармонії в композиції, що пов'язана з умінням ураховувати в конструкції функціональність і умови експлуатації, особливості композиції форми, умови середовища, де буде використовуватись цей виріб (колір і світло).

Для успішного виконання декоративного оздоблення виробів шляхом імітації природних матеріалів учні вчаться імітувати такі природні матеріали, як деревина, пластмаси, каміння, тканини, шкіра та інші. Окрім цього вони повинні набути навички роботи з аквареллю, гуашшю, масляними фарбами.

Розробляючи художньо-конструкторську документацію на виріб, що проектується, учні засвоюють уміння щодо складання ескізного проекту, 
виконання рисунків, робочих креслень деталей, загального виду виробу в ортогональних проекціях і перспективі, виготовлення їх робочих моделей.

3 урахуванням вимог, які висуваються до виробів, що розробляються, до їх призначення, до матеріалів, що використовуються, декоративного оздоблення учням необхідно вміти виконувати моделювання або макетування виробу.

Одним із важливих чинників, що впливає на якість виробів є вибір відповідних його призначенню, конструкції i характеру експлуатації конструкційно-оздоблювальних матеріалів. Отже, ці уміння також $\epsilon$ необхідними учням на уроках технології.

У навчанні стоїть задача не навчити людину розв'язувати окремі типи протиріч, а розвивати творче мислення, уміння в кожному випадку висовувати передбачення, вибирати серед них гіпотезу, доводити іï, робити відповідні висновки. Творчі технічні задачі призначені розвивати в учнів ці якості, тобто розвивати технічне мислення.

Виходячи 3 аналізу теоретичної розробленості, практичного використання і значущості проблеми дизайнерської освіти, можна стверджувати, що логіка педагогічної теорії і практики на сучасному етапі висуває до порядку денного абсолютно специфічну задачу: формування в учнів особливого типу мислення, яке можна назвати «дизайнерським мисленням».

До компонентів дизайнерського мислення ми віднесли знання про колір, просторові співвідношення, елементи технічної естетики, розуміння художніх особливостей спільності предметів, об'єднаних ансамблів, розуміння доцільності в оцінюванні предметів, раціональності і гармонійності речі.

Саме керуючись ним як комплексом, що складається 3 особливої установки свідомості, оцінних думок і способів творчої діяльності, людина може формувати в собі естетичне ставлення до світу речей.

Висновки. Шляхом цілеспрямованої роботи можна прогнозувати формування основ елементів особливого стилю мислення, яке ми назвали дизайнерським мисленням, для якого характерне розуміння основних критеріїв гармонійної речі (доцільність і естетична виразність), стильове чуття, естетичне ставлення до світу речей довкілля. Обгрунтувано, що формування елементів такого мислення найуспішніше здійснюється за дотримання певних організаційно-педагогічних умов: навчально-дизайнерських, соціальноемоційних, дидактичних, індивідуально-творчих.

Актуальними напрямками подальшої розроблення окреслюваної проблеми $є$ вивчення питання щодо вдосконалення змісту дизайнерських знань учнів і переходу від алгоритмічних до евристичних способів рішення художньо-конструкторських задач.

\section{Література}

1. Волкотруб И.Т. Основы художественного конструирования. Моделирование материалов и биоформ / И.Т. Волкотруб. - К. : Высшая школа, 1982. -152 с.

2. Даниленко В.Я. Основы дизайна: [учеб. пособ.] / В.Я. Даниленко. - Х. : ХДАДМ, 2003. - 118 c. 
3. Тасалов В.И. Теория дизайна и проектная культура / В.И. Тасалов // Техническая эстетика. - 1991. - № 7. - С.9.

Стаття надійшла до редакції 01.06.2012 р.

УДК 378.147:371.311.4

A. О. Кравцова,

асистент,

Криворізький педагогічний інститут ДВНЗ «Криворізький наиіональний університет»

\section{ПІДГОТОВКА СТУДЕНТІВ ПЕДАГОГІЧНИХ ФАКУЛЬТЕТІВ ДО ОРГАНІЗАЦІЇ ГРУПОВОЇ ФОРМИ НАВЧАННЯ УЧНІВ}

Кравиова А. О. Підготовка студентів педагогічних факультетів до організаиії групової форми навчання учнів.

У статті розглянуто питання підготовки студентів педагогічних факультетів до організації групової форми навчання учнів. Групова робота сприяє індивідуалізації процесу навчання, забезпечує використання знань у повному обсязі, підвищує відповідальність за кінщеві результати навчання.

Ключові слова: підготовка майбутніх учителів, групові форми навчання, педагогічні умови, колективне розв'язання, індивідуалізація прочесу навчання.

Кравиова А. А. Подготовка студентов педагогических факультетов к организачии групповой формы обучения учащихся.

В статье рассмотрен вопрос подготовки студентов педагогических факультетов $\kappa$ организации групповой формы обучения школьников. Групповая работа способствует индивидуализации процесса обучения, обеспечивает использование знаний в полном объёме, повышает ответственность за конечные результаты обучения.

Ключевые слова: подготовка будущих учителей, групповые формы обучения, педагогические условия, коллективное решение, индивидуализаџия процесса обучения.

Kravtsova A. Pedagogical faculty students training in schoolchildren organization of group forms learning.

The article deals with the problem concerning Pedagogical faculty students training in schoolchildren organization of group forms learning. Group activities stimulates individualization in the process of learning, guarantees the use of knowledge in full, increases one's responsibility for final results of learning material.

Key words: future teachers training, group forms of learning, pedagogical conditions, collective decision, individualization in the process of learning.

Постановка проблеми. Модернізація освіти потребує створення нової школи - психологічно й соціально необхідної для дитини, яка розвивається, для молоді з їі кризою самосвідомості і самовираження. Іншими словами, назріла необхідність розроблення нової моделі педагога, важливим компонентом якої $є$ професіоналізм учителя 3 інноваційним мисленням. Для цього недостатньо загальної ерудиції, інформаційної освіченості у системі соціальних знань. На першому місці має бути цілісна зрілість фахівця, уміння обирати пріоритети у своїй фаховій діяльності. Для вчителя початкової школи це завдання є на порядок вищим у порівнянні з іншими професіями.

На цьому акцентував увагу В. Сухомлинський, називаючи учительську професію людинознавством, наголошував, що від педагога залежить, чим стане серце дитини - «ніжною квіткою чи засушеною корою» [5]. 